\title{
The Linkage Between Economic Growth and Deforestation in OIC (The Organisation of Islamic Cooperation) Countries
}

\author{
Rani Puspitaningrum \\ Master Candidate of Islamic \\ Economics, Postgraduate School of \\ Universitas Airlangga, Surabaya, \\ Indonesia
}

rani.puspitaningrum-

2015@pasca.unair.ac.id

\author{
Raditya Sukmana \\ Department of Islamic Economics, \\ Faculty of Economics and Business, \\ Universitas Airlangga, Surabaya, \\ Indonesia,
}

raditya-s@feb.unair.ac.id

\author{
Imron Mawardi \\ Department of Islamic Economics, \\ Faculty of Economics and Business, \\ Universitas Airlangga, Surabaya, \\ Indonesia
}

ronmawardi@feb.unair.ac.id

\begin{abstract}
The issue between economic growth and the environment is interesting when it is studied further. Deforestation is one of the greatest environmental issues requiring serious public concern. This study examines the effect of gross domestic product per capita, agricultural land, exports and foreign direct investment towards deforestation in the 12 OIC member countries over 14 years from 1997-2014 using an Auto Regressive Distributed Lag (ARDL) with Generalised to Specific Models (GTSM) technique. The results showed that in the long-term.x , gross domestic product per capita, export, foreign direct investment, and agricultural land have a significant effect. Meanwhile, in the short-term, agricultural land and exports showed significantly at a statistical level.
\end{abstract}

Keywords; economic growth; deforestation; Auto Regressive Distributed Lag (ARDL); Islam

\section{INTRODUCTION}

Deforestation is one of the most serious environmental problems facing society today. Deforestation is the conversion of forest land use to non-forest areas such as agricultural land, grasslands, logging areas, residential land and abandoned land, without sufficient effort to restore forest functions. The total area of forest in the world was estimated to be around 4 billion hectares in 2005 , covering $30 \%$ of the total land area while the rate of deforestation is estimated to be million hectares per year. This leads to considerable losses that include biodiversity loss, hydrologic cycles, soil erosion, landslides, atmospheric pollution, drastic climate change, and so on (Nai'ya, 2007).
The underlying causes of deforestation stated by Angelsen and Kaimowitz (1999) include the level of macroeconomic change and policy instruments that affect markets, new technology, information dissemination, infrastructure and institutional developments, particularly property regime. The underlying macro-economic indicators include population, income level, economic growth, foreign debt, devaluation and free trade. Thus, it is assumed that when the underlying causes of deforestation can be minimised, other causes will be controlled so that the rate of deforestation will also gradually diminish

Several previous studies have discussed the relationship between deforestation and economic growth from various points of view such as Waluyo \& Terawaki (2016), Rahim \& Shahwahid (2009), Ahmad et.al. (2016), Alege \& Ogundipe (2013), Wijesinghe \& Pachalingam (2016), and Ahmed et.al (2015) which focuses only on one country with time series data. A comprehensive research study using panel data with discussions related to Islamic economics perspectives is deemed necessary. In fact, the research analysis of the economic growth related to deforestation in the OIC member countries (the Organisation of Islamic Cooperation) has not been estimating empirically. It is the reason why the researchers take it as an opportunity to fill in the gaps in the previous studies. In an argument that increasing the economic growth in countries that implement the Islamic economic system such as OIC member countries, the level of environmental problems in general and deforestation, in particular, will be diminished due to the citizens' awareness that puts the moral and religious aspect in to the context of maintenance of the environment and surrounding natural resources. 


\section{LITERATURE REVIEW}

\section{A. Linkage between Deforestation and Economic Growth}

Deforestation and economic growth are worldwide attention issues. There is a relationship between increasing economic growth and pressures on the environment. In other words, at the initial stage of economic growth marked by the GDP growth of a region, this will be followed by environmental damage which will slow down at the specific point of income level (Dinda, 2004). This systematic relationship is also described as the Environmental Kuznets Curve (EKC) by Kuznets (1995). He states in his EKC hypothesis that the initial phase of a country's economic development is characterised by the expansion of the agricultural sector and forest clearance. In a short period of time, increased revenues may increase the demand for agricultural products that encourages the expansion of agricultural land and creates massive deforestation (Angelsen $\&$ Kaimowitz, 1999). Then, when a country gets enough capital accumulated as a result of land clearing, the industrial sector begins to flourish and offers higher rental rates of production than the agricultural sector. It is for this reason that the farmers leave their land and move to the city in the hope of working in the manufacturing industry that promises far greater wages.

Along with the urbanisation pattern, agricultural intensification occurs as a result of additional capital. At the same time, the demand pattern for agricultural products has changed and people are beginning to consume non-agricultural products. This macro pattern combination can lead to a decrease in deforestation rates (Gibbs et al, 2010).

\section{B. Deforestation Issues in OIC Member Countries}

Muslim countries that are OIC members have a large variety of natural resources. Most of them have an arid and semi-arid geographic profile that means that the majority of member states are in desert environments, especially countries in the Middle East and North Africa. Such conditions make them vulnerable to climate change related to water availability for agricultural purposes. This kind of environment is also characterised by small areas of forest. Countries located in Africa such as Comoros, Togo, and Nigeria are among the countries with the highest rates of deforestation. In addition to increased urbanisation in most OIC member countries (United Arab Emirates (UAE), Bahrain, Malaysia, and Turkey), this has caused pressure on forest areas due to the enormous energy use in the country (Vaghefi et al., 2015). Furthermore, some evidence related to urbanisation as one of the causes of deforestation is also revealed in the case of Indonesia. World Bank data mentions that in 1990, the urban population reached about $30 \%$ of the total population and continued to rise by $50 \%$ in 2010. During that period, deforestation in the country also increased and it was noted that the clearing of forest land functioned to meet export demands (Leblois et.al., 2016).

\section{Ethical Conduct of Deforestation in Islam}

Islam teaches that all economic activities undertaken by man cannot be separated from the natural and ecological balance. The socio-economic justice paradigm is the ultimate goal so it is advisable not to overstate the consumption of goods and to make just distribution (Chapra, 1996). Human activities are expected to utilise natural resources as well as making it possible to achieve human welfare without damaging the environment as stated in the Qur'an surah (02:11) and anyone who does damage, such as cutting down trees without any justification, will get the wrath of God (Abu Dawud 036: 5220: Narrated By Abdullah ibn Habashi).

Prophet Muhammad (pbuh) also created a special area devoted to the preservation of plants and animals called Hima and Haram. This tradition was also practiced in the Caliphate of the Apostles' companions and encouraged people to cultivate for the development of forests and natural resources. It has also been mentioned in some authentic hadiths that planting plants and trees will be rewarded in the world and in the hereafter (Ahmed and Monjur, 2010). This was stated by Muhammad (pbuh) in hadith narrated by Imam Bukhari, Muslim and Tirmidhi, from Anas 010: 3769, Chapter 023.

\section{METHODOLOGY}

This paper aims to examine the long- and short-term relationship between economic growth and deforestation in the 12 OIC member countries which includes: Bahrain, Brunei Darussalam, Bangladesh, Indonesia, Iran, Kuwait, Malaysia, Nigeria, Pakistan, United Arab Emirate (UAE), Sudan and Turkey by using an Auto Regressive Distributed Lag (ARDL) with the Generalised To Specific Models (GTSM) technique. The data of the research sample is 14 years of annual data from 1997-2010 obtained from various sources i.e. World Bank, FAO (Food and Agriculture Organization) and IMF (International Monetary Fund).

The research variables in this study are deforestation [HUT] which proxies as forest area, economic growth as a percent change of gross domestic product per capita [GDP]. The author also includes other variables based on the consideration that economic growth is not the only affecting factor of deforestation. The variables are agricultural land [AGR], export [EXO] and foreign direct investment [FDI].

\section{A. Research Model Equation}

The general empirical model of this research is as follows:

$$
H U T=c+\beta 1 G D P t+\beta 2 A G R t+\beta 3 E X O t+\beta 4 F D I t+\mu t
$$

HUT represents forest area in a hectare (ha), GDP represents the percent change of gross domestic product per capita in USD, AGR is the agricultural land area in a hectare (ha), EXO is a log of agricultural and forestry product export in USD, and FDI represents the log of foreign direct investment in USD. $\beta 1, \beta 2$, $\beta 3, \beta 4$ and $\beta 5$ are a coefficient of each variable. $\mathrm{C}$ is constant, while $\mu$ t is error term. 
The Auto Regressive Distributed Lag (ARDL) is a standard Least Square Regression that includes the lag of the dependent and independent variables as regressors (Greene, 2008 in Anonymous, 2016: 283) and often used in previous studies related to deforestation and economic growth (Ahmad, Bano, Zhao, \& Afzal, 2016; Rahim \& Shahwahid, 2009; and Waluyo \& Terawaki, 2016). Ekananda (2016: 183) states that it is an econometric method that assumes that a variable is influenced by the variable itself, but in a previous time.

The ARDL equation model for each country can be written asfollow:

$$
\begin{aligned}
& \Delta H U T t=c+\sum_{i=1}^{p} \alpha 1 i \Delta H U T t-i+\sum_{i=0}^{p} \alpha 2 i \Delta G D P t-i+\sum_{i=0}^{p} \alpha 3 i \Delta A G R t-i+ \\
& \sum_{i=0}^{p} \alpha 4 i \Delta E X O t-i+\sum_{i=0}^{p} \alpha 5 i \Delta F D I t-i+\beta 0 H U T t-1+\beta 1 G D P t-1+\beta 2 A G R t-1 \\
& +\beta 3 E X O t-1+\beta 4 F D I t-1+\varepsilon t
\end{aligned}
$$

The long-term equilibrium coefficient estimation models can be written as follows:

$$
\begin{aligned}
& \text { HUTt }=c+\phi 1 i \sum_{i=1}^{p} H U T i, t-i+\phi 2 i \sum_{i=1}^{p} G D P i, t-i+\phi 3 i \sum_{i=1}^{p} A G R i, t-i \\
& +\phi 4 i \sum_{i=1}^{p} \text { EXOi, } t-i+\phi 5 i \sum_{i=1}^{p} F D I i, t-i+\mu t
\end{aligned}
$$

While the short-term equilibrium relationship coefficient estimation can be written as follows:

$$
\begin{aligned}
& \Delta H U T t=c+\sum_{i=1}^{p} \gamma 1 i \Delta H U T t-i+\sum_{i=1}^{p} \gamma 2 i \Delta G D P t-i+\sum_{i=1}^{p} \gamma 3 i \Delta A G R t-i \\
& +\sum_{i=1}^{p} \gamma 4 i \Delta E X O t-i+\sum_{i=1}^{p} \gamma 5 i \Delta F D I t-i+\gamma 7 E C T t-1+\mu t
\end{aligned}
$$

information criterion refers only to one candidate lag (Ekananda, 2016: 266).

After the optimum lag length, further analysis was done for hypothesis testing using the ARDL method with a GTSM approach on the long-term equation model (3) to estimate the long-term coefficients. Finally, the error correction representation of the ARDL model was chosen after we estimated the long-term coefficients. Error Correction Model $(\mathrm{ECM})$ is an extended ARDL model with an error correction term (ECT) to estimate the short-term coefficient using equation (4).

\section{RESULT}

The Pedroni (2004) cointegration method is a cointegration test based on Engle and Granger (1987), based on the residual examination of a false regression performed using I(1) variables. If the variable is cointegrated, the residual must be I(0) and if not, it will be I(1). Pedroni (1999, 2004) and Kao (1999) extended the Engle-Granger frameworks for testing cointegration involving panel data. The following table is the Pedroni test results:

TABLE I. PEDRONI COINTEGRATION TEST RESUlT

\begin{tabular}{|l|l|l|}
\hline & Statistic & \multicolumn{2}{|c|}{ Prob. } \\
\hline Panel v-statistic & -3.251617 & 0.9994 \\
\hline Panel rho-statistic & 3.267032 & 0.9995 \\
\hline Panel PP-statistic & -4.420476 & $0.0000^{* * *}$ \\
\hline Panel ADF-statistic & -2.927873 & $0.0017^{* * *}$ \\
\hline Group rho-statistic & 4.170593 & 1.0000 \\
\hline Group PP-statistic & -4.804069 & $0.0000^{* * *}$ \\
\hline Group ADF-statistic & -1.200365 & 0.1150 \\
\hline
\end{tabular}

$* * *, * *$ and $*$ denotes significant at $1 \%, 5 \%$ dan $10 \%$ respectively

\section{B. Data Analysis}

We began to analyse whether the variables are cointegrated using Pedroni's (2004) cointegration methods as used by Asongu et.al. (2016) in the context of the relationship between energy consumption, carbon emissions, and economic growth in 24 countries in Africa with an ARDL panel approach. If the null hypothesis of cointegration between the variables is accepted, we can proceed to the next step by determining the optimum lag length structure to test the hypothesis on long- and short-term dynamic equation models. The selected lag is according to the Likelihood Ratio (LR), Final Prediction Error (FPE), Akaike Information Criterion (AIC), Schwarz Information Criterion (SC), and Hannan-Quin Criterion (HQC). We found that the optimum lag of the variable is if the
Table I shows the significance value of Panel v-Statistic Panel rho-Statistic which means that the null hypothesis (H0) that states the acceptance of no cointegration relationship is rejected. In other words, it is found that cointegration exists between variables in this research. We expect that all of the research variables namely forest area, gross domestic product per capita, agricultural land, export and foreign direct investment have a relationship regarding economic and environmental issue.

We continued to determine the optimum lag length structure requirement in the ARDL equation model. Testing optimum lag is very useful to eliminate the problem of autocorrelation that affects the acceptance and rejection of the null hypothesis in 
bias estimation and inaccurate predictions (Ekananda, 2016: 266).

TABLE II - OPTIMUM LAG LENGTH STRUCTURE

\begin{tabular}{|c|c|c|c|c|c|c|c|c|}
\hline $\begin{array}{c}\text { No } \\
\cdot\end{array}$ & $\begin{array}{c}\text { Varia } \\
\text { bles }\end{array}$ & Log R & LR & FPE & AIC & SC & HQ & Lag \\
\hline 1. & HUT & -880.8 & 38.4 & $3.09 \mathrm{E}+09$ & 24.7 & 24.9 & 24.8 & 7 \\
\hline 2. & GDP & -1611 & 28.3 & $2.05 \mathrm{E}+18$ & 45.0 & 45.3 & 45.1 & 8 \\
\hline 3. & AGR & -1201 & 302.8 & $1.91 \mathrm{E}+13$ & 33.4 & 33.5 & 33.4 & 1 \\
\hline 4. & EXO & -1430 & 13.3 & $1.37 \mathrm{E}+16$ & 39.9 & 40.3 & 40.1 & 8 \\
\hline 5. & FDI & -1680 & 58.5 & $1.16 \mathrm{E}+19$ & 46.7 & 46.8 & 46.8 & 1 \\
\hline
\end{tabular}

***,** and * significant at 10\%, 5\% dan $1 \%$ respectively

Table II shows that the optimum lag length structure for each variable of HUT, GDP, AGR, EXO and FDI is based on Schwarz Information Criterion (SC) is $(7,8,1,8,1)$ due to its significances. According to the results of the data analysis using the ARDL method, the R-square value of 0.99 means that the variation of the explanatory variables (GDP, AGR, EXO and FDI) used in the research model are able to explain $99 \%$ of the response variable variation (HUT), while the remaining $1 \%$ is influenced or explained by other variables not included in this research model. Furthermore, the estimation of a long-term coefficient is given below:

TABLE III - LONG-RUN COEFFICIENT ESTIMATION RESULT

\begin{tabular}{|c|c|c|c|c|}
\hline Variables & Coefficient & Standard Error & t-Statistic & Prob. \\
\hline C & -11615.96 & 6631.28 & -1.75 & 0.086 \\
\hline GDP & $7.46 \mathrm{E}-07$ & $4.02 \mathrm{E}-07$ & 1.78 & $0.081^{*}$ \\
\hline EXO & -0.000102 & $4.57 \mathrm{E}-05$ & -2.23 & $0.030^{* *}$ \\
\hline FDI & $2.51 \mathrm{E}-06$ & $9.07 \mathrm{E}-07$ & 2.77 & $0.008^{* * *}$ \\
\hline GDP(-7) & $-1.06 \mathrm{E}-06$ & $6.52 \mathrm{E}-07$ & -1.62 & 0.111 \\
\hline AGR(-1) & 0.000517 & 0.000212 & 2.43 & $0.018^{* * *}$ \\
\hline EXO(-1) & 0.000212 & $4.72 \mathrm{E}-05$ & 4.49 & $0.000^{* * * *}$ \\
\hline EXO(-2) & $-5.92 \mathrm{E}-05$ & $3.45 \mathrm{E}-05$ & -1.72 & $0.092^{*}$ \\
\hline EXO(-3) & -0.000575 & $4.86 \mathrm{E}-05$ & -11.83 & $0.000^{* * * *}$ \\
\hline EXO(-5) & 0.000393 & $4.14 \mathrm{E}-05$ & 9.49 & $0.000^{* * * *}$ \\
\hline EXO(-6) & 0.000376 & $8.20 \mathrm{E}-05$ & 4.58 & $0.000^{* * * *}$ \\
\hline EXO(-7) & 0.000120 & $3.82 \mathrm{E}-05$ & 3.14 & $0.003^{* * * *}$ \\
\hline EXO(-8) & -0.000287 & $4.02 \mathrm{E}-05$ & -7.13 & $0.000^{* * * *}$ \\
\hline FDI(-1) & $-1.63 \mathrm{E}-06$ & $8.79 \mathrm{E}-07$ & -1.85 & $0.069^{*}$ \\
\hline & & & & Source: Eviews 9 \\
\hline
\end{tabular}

$* * *, * *$ and $*$ significant at $1 \%, 5 \%$ dan $10 \%$ respectively
Table III shows that in the long-term, GDP, AGR, EXO, and FDI significantly affect deforestation at $10 \%, 5 \%, 5 \%$ and $1 \%$ respectively. The positive coefficient of GDP is interpreted as if GDP increases, the forest area will increase but deforestation decreases. The positive long-term coefficient results of this study were supported by Rahim and Shahwahid (2009) but found to be insignificant in their research. The argument of an increasing gross domestic product can reduce the pressure on forests by improving off-farm employment opportunities as stated by Angelsen and Kaimowitz (1999). Countries with increasing incomes may also demand that the forests be protected rather than depleted. If national income rises, peoples get a more alternative livelihood in other economic sectors which promises greater wages than activities that encourage deforestation. Gross domestic product per capita coefficient shows the value of 0.0000746 which means that the $1 \%$ increasing gross domestic product per capita will decrease deforestation by $0.0000746 \%$ respectively.

The long-term coefficient of agricultural land was found to be positive to the forest area and negative to deforestation at a value of 0.000517 . The coefficients mean that $1 \%$ of the increasing agricultural land will decrease deforestation by $0.000517 \%$. It may be presumed that the changes in the forest area in OIC member countries are not only used for extensive agricultural land (plateau or forest edge) but also for intensive agriculture (lowland). Other conservation policies on intensive agriculture (e.g. supports productive inputs other than land policy) can reduce deforestation.

In addition, the development of agricultural technology such as the improvement of irrigation systems in lowland agriculture supports forest conservation without reducing the incentives derived from the agricultural sector as stated by Angelsen et.al. (2010: 131) in the case of an irrigation system in the Philippines. They said that it also attracts labour from extensive to intensive agriculture. An increased in intensive agricultural production can decrease domestic agricultural product prices which subsequently reduces the value of extensive agricultural rents and deforestation rate (Jayasuriya, 2001 in Angelsen et al., 2010: 131).

The long-term coefficient of foreign direct investment was found to be positive within the forest area. The coefficient value of foreign direct investment is 0.00000251 . It can be interpreted as a $1 \%$ increase in foreign direct investment will decrease deforestation by $0.00000251 \%$. This result was supported by Alege and Ogundipe (2013) in the context of the impact of foreign direct investment on carbon emissions in Nigeria. This is based on the foreign investment in these countries being used for supporting environmental conservation in economic activities, especially in forestry preservation. Furthermore, the aim of the investment is to gain a profit that is not the only purpose of OIC member countries, as deforestation is reduced by long-term foreign investment. It is principal to a Muslim country to avoid the sole purpose of maximising profits in economic activities by ignoring the environmental balance of the forest ecosystems which are essential to the lives of present and future generations. 
Exports have a various long-term coefficient result but they need to be significant at any statistical level. The coefficient value of exports is 0.000102 which means that $1 \%$ increasing export will increase deforestation by $0.000102 \%$. The result is supported by Danquah et.al (2013) in the context of the causal relationship between Ghana mahoganies export and deforestation. In addition, export in any major lag is found to be positive within a forest area. It means that increasing exports will increase the forest area and decrease deforestation automatically. However, this result is contradictory in lag 2, 3 and 8. An argument of the positive significant lags is because the data of exports used in this study was legally provided by authorised bodies. This is why the results show that majority increasing exports in OIC countries will reduce deforestation in the long-term.

TABLE IV - Short-Run Coefficient Estimation Result

\begin{tabular}{|l|l|l|l|l|}
\hline Variables & Coefficient & \multicolumn{1}{|c|}{$\begin{array}{c}\text { Standard } \\
\text { Error }\end{array}$} & t-Statistic & Prob. \\
\hline $\mathrm{C}$ & -3504.24 & 3057.278 & -1.146 & 0.257 \\
\hline $\mathrm{D}(\mathrm{AGR}(-))$ & 0.001417 & 0.000556 & 2.550 & $0.014^{* *}$ \\
\hline $\mathrm{D}(\mathrm{EXO}(-3))$ & -0.000159 & $4.59 \mathrm{E}-05$ & -3.459 & $0.001^{* * *}$ \\
\hline $\mathrm{D}(\mathrm{EXO}(-5))$ & 0.000369 & $5.40 \mathrm{E}-05$ & 6.839 & $0.000^{* * *}$ \\
\hline $\mathrm{D}(\mathrm{EXO}(-6))$ & $9.46 \mathrm{E}-05$ & $3.67 \mathrm{E}-05$ & 2.577 & $0.013^{* * *}$ \\
\hline $\mathrm{D}(\mathrm{EXO}(-7))$ & 0.000255 & $4.25 \mathrm{E}-05$ & 5.999 & $0.000^{* * * *}$ \\
\hline $\mathrm{D}(\mathrm{EXO}(-8))$ & -0.000109 & $2.58 \mathrm{E}-05$ & -4.217 & $0.000^{* * *}$ \\
\hline $\mathrm{ECT}(-1)$ & -0.356064 & 0.191901 & -1.855 & $0.070^{*}$ \\
\hline
\end{tabular}

$* * *, * *$ and $*$ significant at $1 \%, 5 \%$ dan $10 \%$ respectively

Table IV shows that the variables influencing deforestation in the short-term are AGR and EXO at the level of significance $5 \%$ and $1 \%$, while GDP and FDI are insignificant. Positive and significant coefficients explain the relationship or influence between agricultural land and deforestation over one year, suggesting that increasing agricultural land will increase forest land, so deforestation reduces. This result is contrary to the theory conveyed by Angelsen and Kaimowitz (1999), as well as the research conducted by Waluyo and Terawaki (2016). Angelsen and Kaimowitz's state that the change of forest land to agriculture is an implication of the high demand for food and the price of agricultural products are an immediate-cause for deforestation. However, Waluyo and Terawaki also found a negative coefficient between agricultural land and deforestation as well as ongoing research. If we look at the data of land usage areas provided by FAO, most countries in our research are not forested area. They are desert or semi-desert areas, especially Middle Eastern countries such as the Sudan, Pakistan, Bahrain, Kuwait, etc. This factual data had the implication that the change of land area into agricultural land which previously was not forest area, hence, the increasing agricultural land will also increase the forest area during the research period simultaneously.

Economic growth and foreign direct investment have no significant effect in the short-term on deforestation. The insignificant results of economic growth towards deforestation are supported by Rahim and Shahwahid (2009). The explanation of these results may rely on the clearing of the forest area to be used for economic activities to gain sufficient capital accumulation and an emerging industrial sector signalling that the increase of economic growth takes considerable time. The data of the gross domestic product per capita is fluctuating and recorded on an annual basis, so it is understandable that the effects cannot be seen shortly. The insignificant results of foreign direct investment can be explained by the economic crisis period of 1997-2010 during this study. The condition mentioned affected the existence of foreign investment as the literature states that the economic, social and political stability of a country can influence the investment climate in a country.

Export variables have a significant effect in the short term towards deforestation with variation coefficient on each lag. However, in general, a significant lag indicates a positive coefficient indicating that an increase in exports will increase the area of forests that can reduce deforestation. In theory, rising exports illustrate the high demand for agricultural products and forestry. This condition will encourage higher rates of deforestation. Waluyo and Terawaki (2016) also mentioned that the export of forest products is a variable that represents a direct determinant increasing rate of deforestation. Thus, the difference in the proven results on the significant lags makes it interesting to explore in future research.

Error Correction Term (ECT) in the short-term estimation results are obtained from its long-term model. The coefficient of the ECT(-1) is 0.35 and is negatively significant at $10 \%$ respectively. This means that $35 \%$ disequilibrium is occurring between HUT, GDP, AGR, EXO, and FDI will be corrected again during the year. The negative coefficient indicates a correction mechanism for long-term balance deviation. The result can be supported by the previous chapter and the Pedroni cointegration test.

\section{CONCLUSION}

This study focuses on the impact of economic growth and deforestation on the twelve OIC member states by adding the variables of agricultural land, exports and foreign direct investment as other factors that also affect the occurrence of deforestation. Overall, all of the explanatory variables included in the model have a significant effect on deforestation based on the results of the ARDL method hypothesis test. In other words, the equation model in this study can be used to predict the rate of deforestation over time in both cross- and single-country contexts. 


\section{References}

[1] Ahmad, Ashfaq., Bano, Sadia., Zhao, Yuhuan., and Afzal, Mehreen, "The Relationship of Deforestation, International Trade and Economic Growth in Pakistan," Bulletin of Energy Economics, 2016, 4(2), pp. 145-154.

[2] Ahmed, H. M. Riza and Monjur, M, "Environmental Degradation: An Islamic Perspective," Social Science Review, The Dhaka University Studies, Part-D, 2010, Vol. 27, No. 1, pp. 1-14.

[3] Ahmed, K., Shahbaz, M., Qasim, A., and Long, W, "The Linkages between Deforestation, Energy and Growth for Environmental Degradation in Pakistan," Ecological Indicators, 2015, 49, pp. 95-103.

[4] Alege, P. O., and Ogundipe, A, "Environmental Quality and Economic Growth in Nigeria: A Fractional Cointegration Analysis," International Journal of Development and Sustainability, 2013, 2(2), pp. 1-17.

[5] Angelsen, A., and Kaimowitz, D, "Rethinking the Cause of Deforestation: Lessons from Economic Models," The World Bank Research Observer, 1999, Vol. 14, No. 1, (February), pp. 73-98.

[6] Angelsen, A., Brockhaus, M., Kanninen, M., Sills, E., Sunderlin, W.D., and Westz-Kanounnikoff., Mewujudkan REDD+: Strategi Nasional dan Berbagai Pilihan Kebijakan, Center for International Forestry Research (CIFOR). Bogor, Indonesia, 2010.

[7] Anonymous, Eviews 9 User's Guide II. IHS Global Inc. Irvine, CA. 2016

[8] Asongu, S., Montasser, G. El., and Toumi, H, "Testing The Relationships Between Energy Consumption, CO2 Emissions, and Economic Growth in 24 African Countries: A Panel ARDL Approach," Journal of Environmental Science Pollution Research, 23(2016), pp. 6563-6573

[9] Chapra, M.U, "What is Islamic Economics?" Islamic Research Training and Institute (IRTI), IDB Prize Winners' Lecture Series, 1996, No. 9, pp. $1-76$

[10] Danquah, J. A., Sarpong, D. B., and Pappinen, A., "Causal Relationships between African Mahoganies Exports and Deforestation in Ghana: Policy Implications", Environmental Development Sustainable, 2013, 15, pp. 51-66.

[11] Dinda, S, "Environmental Kuznets Curve Hypothesis: A Survey," Journal of Ecological Economics, 2004, 49, pp. 431-455.
[12] Ekananda, M, Analisis Ekonometrika Time Series Edisi 2. Mitra Wacana Media. Jakarta, 2016

[13] Engle, R. F., and Granger, C. W., "Cointegration and error correction: Representation, estimating and testing," Econometrica, 1987, 55, 251, pp. 76.

[14] Kao, C., "Spurious regressions and residual-based test for cointegration in panel data," Journal of Econometrics, 1999, 90, pp. 1-44.

[15] Kuznets, P., Simon., "Economic growth and income inequality," American Economic Review, 1995, 45, pp. 1-28.

[16] Leblois, A., Damette, O., and Wolfersberger, J, "What has Driven Deforestation in Developing Countries Since the 2000s? Evidence from New Remote-Sensing Data," World Development, 2016, Vol. 92, pp. 82 102.

[17] Nai’ya, Isma'eel Ibrahim, "Environmental issues and Islamic economics: Nature and solutions," Proceedings of the 2th Islamic Conference 2007 (iECONS2007) organized by Faculty of Economics and Muamalat, Islamic Science University of Malaysia.

[18] Pedroni, P., "Critical values for cointegration tests in heteregenous panels with multiple regressors", Oxford Bulletin of Economics and Statistics, 1999, Vol. 61 No. 1, pp. 653-670.

[19] Pedroni, P., "Panel Cointegration: Asymptotic and Finite Sample Properties of Pooled Time Series Tests with An Application to The PPP Hypothesis," Journal of Econometric Theory, 2004, 20(3), pp. 597-625.

[20] Rahim, A. S. A., and Shahwahid, H.O. Mohd S, "Determinants of Deforestation in Peninsular Malaysia: An ARDL Approach. The Malaysian Forester, 2009, 72(2), pp. 19-28.

[21] Waluyo, E. A., and Terawaki, T., "Environmental Kuznets Curve for Deforestation in Indonesia: An ARDL Bounds Testing Approach," Journal of Economic Cooperation and Development, 2016, 37, 3, pp. 87108.

[22] Wijesinghe, A., and Pachalingam, T., "Deforestation and Income Growth in South Asia: An Evidence for Environmental Kuznets Curve", Conference Paper submitted to $8^{\text {th }}$ Biennial Conference of Indian Society for Ecological Economics, Indian Institute of Science, BEngalaru, India, January 4-6 $6^{\text {th }}, 2016$. 